\title{
Do egg parasitoids increase the tendency of Lestes sponsa (Odonata: Lestidae) to oviposit underwater?
}

\author{
Filip HARABIŠ ${ }^{1, *}$, Aleš DOLNÝ $2, *, * *$, JANA HELEBRANDOVÁ ${ }^{2}$ and TeREZA RUSKOVÁ ${ }^{2}$ \\ ${ }^{1}$ Department of Ecology, Faculty of Environmental Sciences, Czech University of Life Sciences Prague, Kamýcká 129, \\ CZ-165 21 Prague 6, Czech Republic; e-mail: harabis.f@gmail.com \\ ${ }^{2}$ Department of Biology and Ecology / Institute of Environmental Technologies, Faculty of Sciences, University of Ostrava, \\ Chittussiho 10,CZ-710 00 Slezská Ostrava, Czech Republic; e-mails: ales.dolny@osu.cz; xaustrik@seznam.cz; \\ P11104@student.osu.cz
}

Key words. Odonata, Lestidae, Lestes sponsa, submerged oviposition, egg parasitism, parasitoids, selection of oviposition site, dragonflies

\begin{abstract}
The selection of oviposition sites by insects can significantly affect egg mortality. Spreadwing damselflies (Odonata: Lestidae) predominantly lay their eggs in parts of plants growing above the surface of water and only occasionally also those parts growing underwater. Factors affecting the choice of oviposition site and decision to lay underwater are still poorly understood. We examined whether localities with different risk of egg parasitism, different oviposition strategies (above or below the water surface) and the depth at which the eggs were laid, affected the total number of eggs laid, the proportion parasitized and egg mortality. In general, a significantly higher proportion of the eggs laid above the surface of water were parasitized but spreadwing damselflies showed significant preference for laying eggs underwater at both of the sites studied. This preference, however, had a different effect on the overall mortality of eggs at the two sites studied. Hence underwater oviposition by damselflies may be seen as a conditional anti-predator strategy, occurring only if the benefits exceed potential risks. Underwater oviposition may provide additional benefits other than protection against egg parasitism.
\end{abstract}

\section{INTRODUCTION}

As eggs are an immobile stage in the life cycle of insects, they are very vulnerable to predation and parasitism. Damselflies lay eggs in several different ways, which may protect the eggs and significantly reduce egg mortality. Each strategy, however, incurs certain risks and energy costs (summarized by Corbet, 1999). The most general classification of the modes of oviposition distinguishes between endophytic and exophytic oviposition, but there is significant variation within these two groups (Corbet, 1999). Several species of dragonflies, of the family Aeshnidae and nearly all damselflies oviposit endophytically, which significantly mitigate the likelihood of their eggs desiccating or freezing and reduces risk of their being eaten by predators (Corbet, 1999). Endophytic oviposition, however, is time-consuming, involves additional energy costs and investment in specific morphological structures, because egg-laying females must insert their eggs into plant tissues (Matushkina \& Gorb, 2007).

Even more time consuming and risky is the strategy of endophytic oviposition in which the adult damselflies lay eggs underwater (Corbet, 1999). Underwater (submerged) oviposition by damselflies is often considered to be an incidental phenomenon as adult damselflies are not adapted to stay submerged in water. However, several studies indicate that some damselflies (the families Calopterygidae and Coenagrionidae) are able to lay eggs after submergence for several dozen minutes (Waage, 1984; Fincke, 1986; Tsubaki et al., 2006; Santolamazza et al., 2011). This leaves the main question unanswered: Why do some species of damselflies prefer this high-cost oviposition strategy, especially when eggs laid in plant tissues are well protected (Corbet, 1999; Martens, 2001). Several hypotheses have been proposed to account for submerged oviposition in damselflies. Fincke (1986) describes the evolution of underwater oviposition as a consequence of sexual harassment and male guarding behaviour. Another hypothesis (Fincke, 1986; Miller, 1994) stresses the importance of interspecific interactions, with endophytic oviposition a means of protecting eggs from abiotic stresses such as drying out and high temperatures and incidental predators but not attack by egg parasitoids (Spence, 1986; Corbet, 1999).

The majority of aquatic parasitoids (about 150 species of Hymenoptera) are generalists, utilizing a wide range of eggs of different host taxa (Fursov, 1995; Bennett, 2008) and idiobionts, parasitoids that prevent further development of their hosts after initially immobilizing them (Askew \& Shaw, 1986; Strand, 1986). Parasitoids may kill a significant percentage of their hosts and so induce many behavioural adaptations in aquatic insects (Spence, 1986; Gibbons \& Pain, 1992; Henriquez \& Spence, 1993; Amano et al., 2008). Several studies on the interactions between the egg parasitoid Tiphodytes gerriphagus (Hymenoptera: Scelionidae) and several species of water striders indicate

\footnotetext{
* The first two authors contributed equally to this work.

** Corresponding author.
} 
that these Hemiptera are able to detect parasitoids (Henriquez \& Spence, 1993; Hirayama \& Kasuya, 2009). In addition, there is evidence that submerged oviposition by water striders could be a behavioural response to a high density of egg parasitoids (Hirayama \& Kasuya, 2009). Although these parasitoids can attack eggs underwater, such attacks are significantly less frequent than of eggs laid above the surface of water (Amano et al., 2008; Hirayama \& Kasuya, 2009). The tendency to lay eggs as deeply as possible is however limited by increasing mortality of eggs at greater depths, their inability to move underwater and so avoid predation and their risk of drowning while laying eggs (Amano et al., 2008; Hirayama \& Kasuya, 2008, 2009).

As noted above, all previous laboratory studies on the effect of parasitoids on the selection by their host of an oviposition site and the occurrence of submerged oviposition were done using water striders. The effects of egg parasitoids on the behaviour of damselflies and other aquatic insects are rarely investigated. This may be important because damselflies have a markedly different oviposition behaviour to that of the taxa previously studied. The aim of the present study is to determine whether L. sponsa has a defensive strategy against egg parasitoids. In addition, we wanted to reveal other potential benefits of underwater oviposition. Two localities with a high and low population density of parasitoids, respectively, were used in this study. Specifically, we addressed: (i) is there a difference in the overall number of eggs laid, the proportion of parasitized eggs or the number of dead eggs (undeveloped or damaged eggs) when L. sponsa lays eggs under or above the surface of the water, (ii) does the depth in the water or height above the water affect the proportion of the above mentioned egg categories. Our study hypotheses were: (1) parasitoids influence damselfly behaviour, therefore in the locality with a low risk of parasitism few eggs should be laid under the surface of the water, whereas in the locality with a high risk of parasitism, the incidence of submerged oviposition should be significantly higher, (2) submerged oviposition is beneficial for damselflies, therefore the percentage of eggs parasitized underwater should be less than above the surface of the water.

\section{MATERIAL AND METHODS}

\section{Study site}

We have only found two locations where individuals of Lestes sponsa (Hansemann, 1823) oviposit underwater. Both are in limestone quarries near Stramberk, in the north-western part of the Czech Republic, The two sites, Locality $1\left(49^{\circ} 35^{\prime} 19^{\prime \prime} \mathrm{N}\right.$, $18^{\circ} 7^{\prime} 28^{\prime \prime} \mathrm{E}, 353 \mathrm{~m}$ a.s.1.) and Locality $2\left(49^{\circ} 34^{\prime} 35^{\prime \prime} \mathrm{N}, 18^{\circ} 7^{\prime} 1^{\prime \prime} \mathrm{E}\right.$, $322 \mathrm{~m}$ a.s.l.), were initially sampled to determine the mortality caused by egg parasitoids. The sites are about $1.5 \mathrm{~km}$ distant from one another and are permanent aquatic pools without fish. The two sites are similar in terms of water surface (about $80 \mathrm{~m}^{2}$ ), physical water properties ( $\mathrm{pH}[7.8-7.9]$, conductivity [270-282 $\mu \mathrm{S} / \mathrm{cm}]$ and dissolved oxygen [67-72\%]), and in their littoral and aquatic vegetation, with Typha, Equisetum and Juncus spp. the dominant plants.

\section{Species studied}

Lestes sponsa is a common species in almost all parts of Europe and Asia (Dijkstra \& Lewington, 2006). Oviposition is predominantly by tandem pairs. The female damselfly lays eggs endophytically. Eggs can complete their development in about 8 weeks (Jödicke, 1997), but those laid in August, undergo winter diapause. Larvae begin to hatch only when the water temperature rises above $13^{\circ} \mathrm{C}$ (Jödicke, 1997). The rate of development inside the egg and survival greatly depend upon ambient temperature (Jödicke, 1997; Corbet, 1999).

Prior to this study, more than 250 submerged ovipositions by tandem pairs were observed. We only scored instances of submerged oviposition when the female was completely submerged (including wings). The majority of $L$. sponsa oviposited underwater. The situation when a female oviposited partially submerged was very rare. This occurred only in situations when the pair was distracted, such as by other males (Dolný et al., 2014).

\section{Submerged oviposition and egg mortality}

Ten days after the last recorded oviposition event $\left(22^{\text {th }}\right.$ August in 2010), random samples of plants were collected at each locality, with five samples at least $2 \mathrm{~m}$ apart collected at each locality. We only sampled Juncus spp. and Equisetum spp., which bear noticeable scars after endophytic oviposition by Lestes. We were not able to distinguish eggs of different species of Lestes, but $L$. sponsa was the most abundant species at both sites. Earlier in the season, when observing the behaviour of L. sponsa, the position of the water level was marked on the stems of plants using a Centropen Paint Marker, which indicated that the water level did not change during the experiment. A random sample of 204 of the collected plants was kept at a temperature of about $10^{\circ} \mathrm{C}$ and processed within ten days of collection. Stems were cut into $5 \mathrm{~cm}$ long segments and their position relative to the surface of the water recorded. All eggs were excised from plant tissues in each segment. Developing, parasitized and dead eggs were visually determined using a dissecting microscope at a magnification of $40 \times$. The development of damselfly and egg parasitoids was relatively fast and therefore also clearly visible. It was possible to distinguish between "developing eggs" and "eggs containing parasitoids" as parasitoid embryos have a completely different body structure (Fig. 1). Unfertilized (undeveloped) and damaged eggs were recorded as "dead eggs" (for illustrations of egg development, see Sternberg \& Buchwald, 1999). Several parasitized eggs were reared in the laboratory in order to identify the parasitoid. Parasitoid wasps were placed in $75 \%$ ethanol and sent to taxonomic specialists. Specimens of Aprostocetus were identified by Victor Fursov, Ukrainian National Academy of Sciences and those of Tetrastichus and Scelionidae by Petr Janšta, Charles University Prague, Czech Republic.

\section{Data analysis}

We used generalized linear models (GLM) to analyse the effects of Locality and position of eggs, Depth, in terms of distance from the surface of the water. Distances were scored as positive if below and negative if above the surface. Response variables were (1) overall number of eggs, (2) proportion of developing eggs, (3) proportion of parasitized eggs and (4) overall mortality. In the analysis where the overall number of eggs was the response variable, we used a model with a quasi-Poisson error distribution (link $=\log$ ) to control overdispersion. For other explanatory variables, we used models with binomial error distribution (link $=$ logit). In the models, number of eggs, proportion of developing eggs, parasitized eggs and total egg mortality were dependent variables. Locality and Depth were always the explanatory vari- 

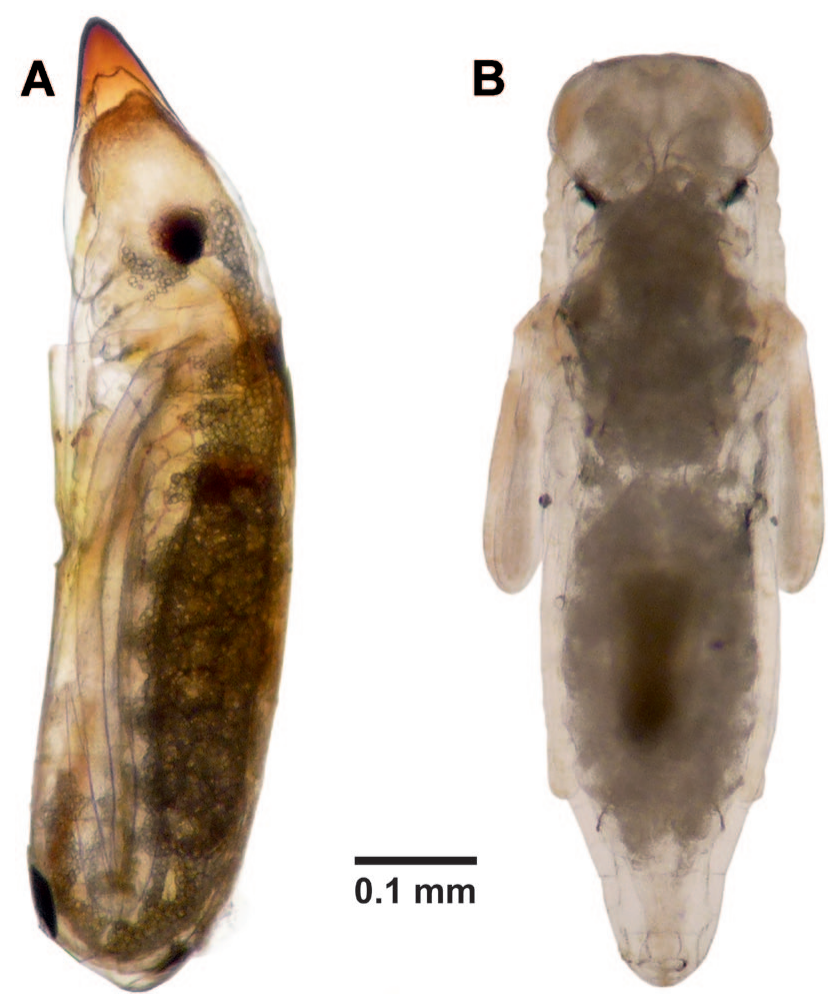

Fig. 1. Eggs of damselflies (Lestes spp.); A - developing embryo (left lateral view); B - egg parasitoid of the genus Tetrastichus (dorsal view).

ables. Oviposition depths based on very few eggs $(<5)$ were not included in the analysis.

All interactions were included in the initial model. Further model simplification (backward selection) was performed using ANOVA and maximum likelihood methods (Crawley, 2007). To test the significance of each variable in the model (i.e. to obtain minimal adequate models), we used chi-squared deletion tests. Statistical significance was established with $\alpha=0.05$. Each minimal adequate model was verified using standard statistical diagnostics (Crawley, 2007). Post hoc comparisons of pairwise differences in number of eggs, proportions of developing and parasitized eggs and the mortality rates in relation to Depth were made by multiple comparisons of means using the Tukey contrasts function in R (Bretz et al., 2010). All analyses were conducted using R 2.13.0 software (R Development Core Team, 2011).

\section{RESULTS}

\section{Mortality caused by egg parasitoids}

A total of 2566 eggs were excised (Locality $1=1113$, Locality $2=1453$ ) from plant tissues. There was a significant tendency to oviposit underwater at both sites, with $69.6 \%$ recorded at Locality 1 and $82.1 \%$ at Locality 2 , while the largest numbers of eggs were laid underwater at depths between 5 and $20 \mathrm{~cm}$ (Fig. 2). The proportion of eggs parasitized was very low at Locality 1 (only one parasitized egg 0-5 $\mathrm{cm}$ above the surface of the water), whereas there was a high proportion of eggs parasitized (n $=258 ; 17.7 \%$ ) at Locality 2 (Fig. 2). The majority of the parasitoids identified belonged to the genera: Aprostocetus Westwood, 1833 and Tetrastichus Haliday, 1844 (Hymenoptera, Chalcidoidea, Eulophidae: Tetrastichinae), plus two male specimens belonging to the family Scelionidae (Hymenoptera, Platygastroidea).

The tendency to lay eggs at a specific depth was only marginally significant, while a significant interaction between Locality and Depth can be seen as the expression of a stronger tendency to lay eggs beneath the surface (at a certain depth) at the site with higher density of egg parasitoids (Table 1, Fig. 3C). The difference between the total numbers of eggs excised at the two sites was highly significant and so Locality was added as a covariate.

The proportion of eggs parasitized was significantly higher for eggs laid above the water surface than for eggs laid underwater (Table 1, Fig. 3C). The highest proportion of eggs parasitized was recorded for those laid $0-5 \mathrm{~cm}$ above the water surface (Tukey HSD: $\mathrm{z}=3.69 ; p=0.012$ ) and this proportion decreased with the depth the eggs were laid underwater (Fig. 3C).

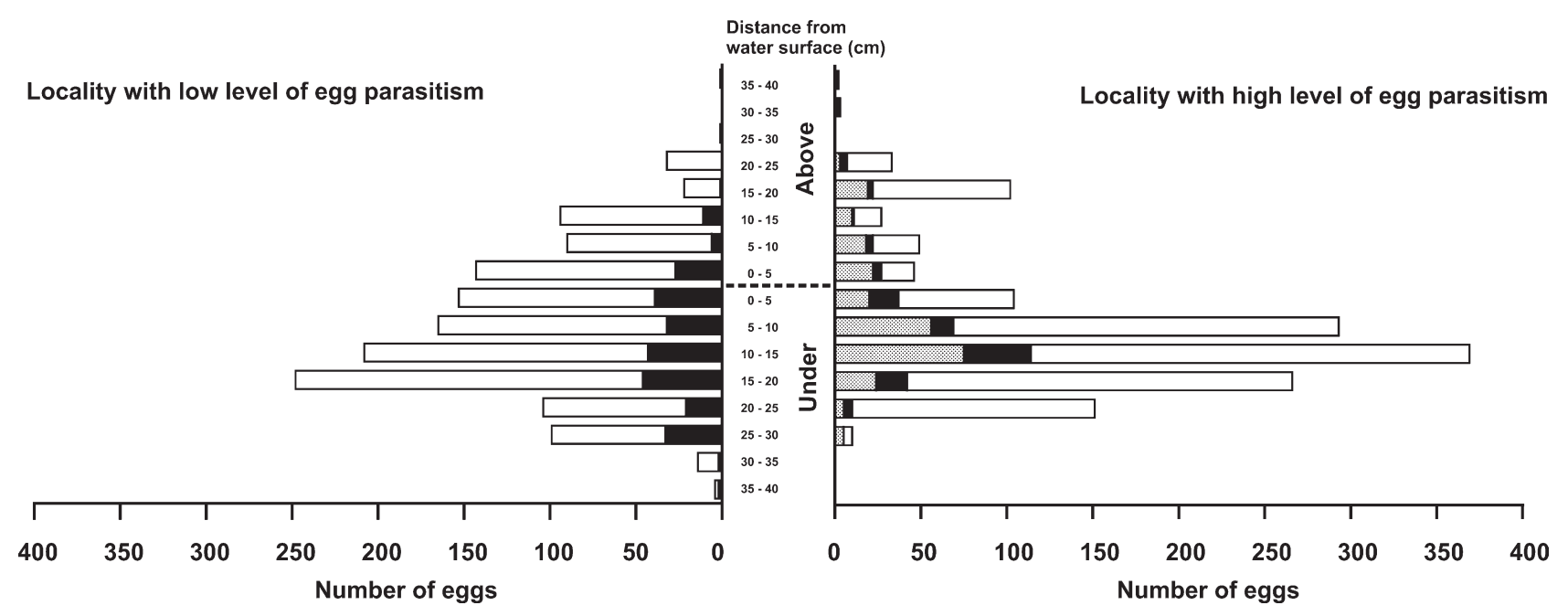

Fig. 2. Proportion of eggs parasitized (grey), dead eggs (black) and developing eggs (white) in relation to distance from the surface of the water and density of parasitoids (by locality). 

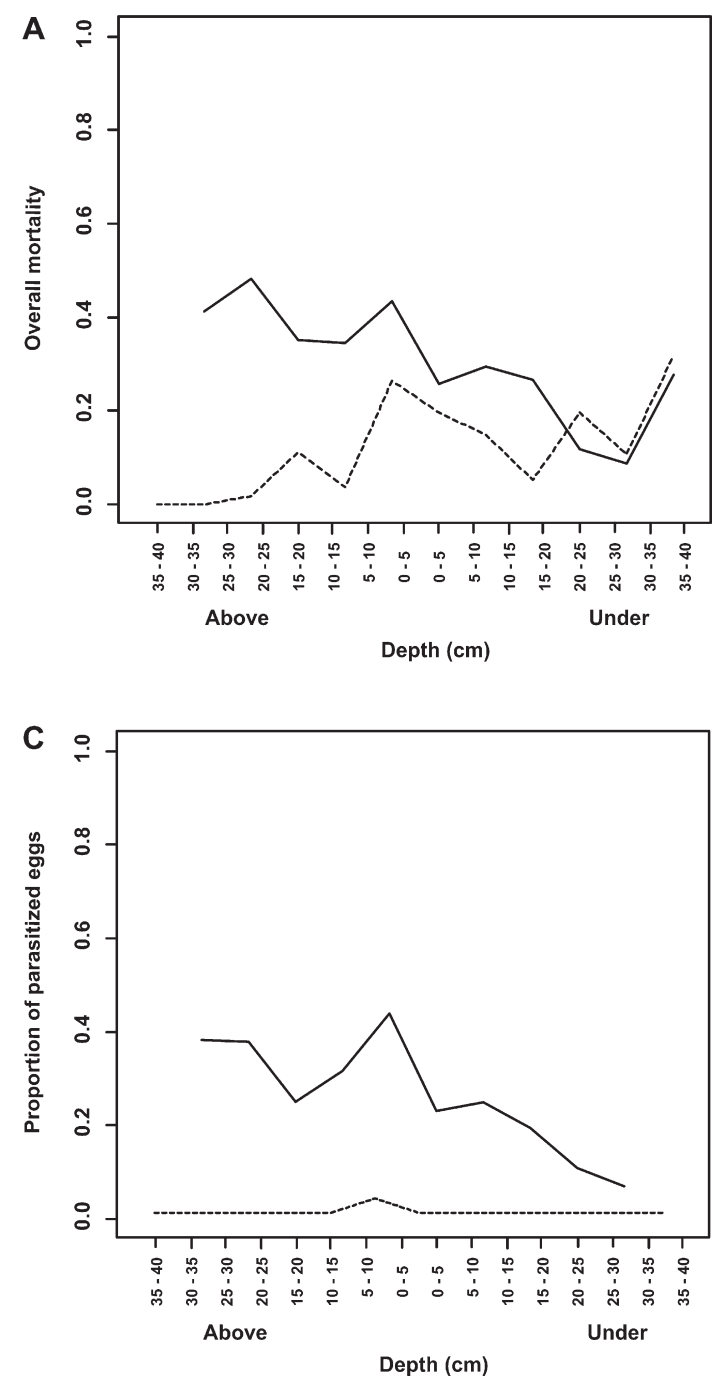

TABLE 1. GLM showing the effect of location and oviposition depth on number of eggs oviposited, egg development (based upon proportions of developing and non-developing eggs), proportion of eggs parasitized and overall egg mortality.

\begin{tabular}{lrrr}
\hline & Df & Deviance & $P(C h i)$ \\
\hline Number of eggs & & & \\
$\quad$ NULL & 1 & 197.05 & $<0.001$ \\
$\quad$ Locality & 12 & 163.80 & 0.054 \\
$\quad$ Depth & 11 & 158.27 & 0.044 \\
$\quad$ Locality : Depth & & & \\
Egg development & 1 & 0.851 & 0.356 \\
$\quad$ NULL & 12 & 103.48 & $<0.001$ \\
Locality & 11 & 86.04 & $<0.001$ \\
Depth & & & \\
$\quad$ Locality : Depth & & & \\
Proportion of eggs parasitized & 1 & 257.48 & $<0.001$ \\
$\quad$ NULL & 12 & 67.10 & $<0.001$ \\
Locality & 11 & 3.06 & 0.990 \\
$\quad$ Depth & & & \\
$\quad$ Locality : Depth & & & \\
Egg mortality & 1 & 3.68 & 0.055 \\
$\quad$ NULL & 12 & 77.91 & $<0.001$ \\
$\quad$ Locality & 11 & 81.98 & $<0.001$ \\
$\quad$ Depth & & & \\
$\quad$ Locality : Depth & & & \\
\hline
\end{tabular}

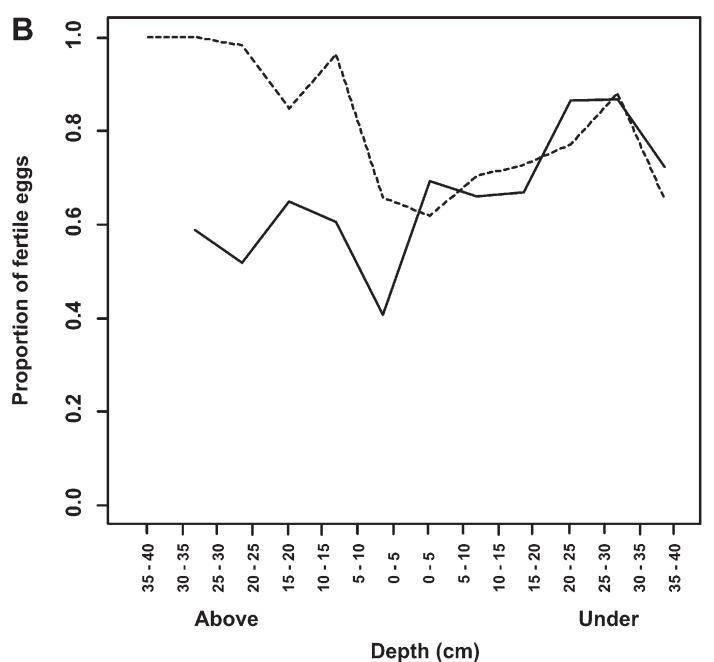

Fig. 3. Overall mortality (A), proportion of developing eggs (B) and proportion of parasitized eggs (C) in relation to egg position (oviposition depth) and locality. Broken line: Locality 1 with a low level of egg parasitization. Solid line: Locality 2 with a high level of egg parasitism. Mortality of eggs caused by egg parasitoids was also included in overall mortality.

\section{Costs of submerged oviposition}

Total mortality and proportion of developing eggs were significantly affected by oviposition Depth (Table 1, Fig. 3A, B). There was also a significant interaction between total mortality of eggs at different localities and oviposition depth (Table 1, Fig. 3A) caused by different proportions of egg parasitism and different development of eggs recorded at both localities and depths (Table 1, Fig. 3B). This means that there was a significant effect of factors other than parasitoids on egg mortality. The highest mortality was recorded near the surface of the water and then for those eggs laid underwater there was a significant increase in mortality and decrease in the proportion of developing eggs with increase in Depth (Table 1).

\section{DISCUSSION}

In accordance with the initial hypothesis, we found that the proportions of eggs oviposited above the surface or underwater depended upon locality, with a stronger tendency to lay eggs underwater at the site with a high risk of predation (including egg parasitism) and other potential stressors. This is consistent with the findings of Hirayama \& Kasuya (2009), who assume that experience of high risk promotes deeper oviposition. Based upon our findings, 
however, it seems the tendency to oviposit underwater may not be associated solely with a high risk of egg parasitism.

The decision to lay eggs underwater is probably affected by many additional factors (preconditions) such as the presence of specific aquatic plants, turbidity or water temperature (Dolný et al., 2014). Several studies on the costs and benefits of submerged oviposition in water striders provide indirect evidence of the existence of a trade-off between egg mortality and the risks associated with laying eggs underwater (Fincke, 1986; Miller, 1994; Amano et al., 2008; Hirayama \& Kasuya, 2010). The results of several studies indicate that the risk of drowning may be relatively low. During our previous observations, all females survived laying eggs underwater (Dolný et al., 2014). The mortality of female damselflies during submerged oviposition is between 0.02 and 0.13 (Fincke, 1986). The overall costs of underwater oviposition consist not just of the risks associated with staying underwater during oviposition but the deeper the eggs are laid the lower their hatchability (Hirayama \& Kasuya, 2010).

As shown in this study, in the absence of a high risk of parasitization, a greater proportion of the eggs laid underwater fail to develop than of those laid above the surface of the water. This might be due to factors associated with an aquatic environment, such as lower concentration of dissolved oxygen and higher water pressure (Miller, 1994; Heywood \& Walling, 2007; Hirayama \& Kasuya, 2010). In accordance with the second hypothesis, we found that a higher proportion of the eggs laid above the surface of the water were parasitized than of those laid underwater, with the proportion of eggs parasitized greatest near the water surface. This is probably related to the searching behaviour of parasitic wasps, which is limited by their inability to move underwater (Corbet, 1999). This is a necessary prerequisite for the hypothesis that proposes that underwater oviposition is an evolutionary response to high predation pressure from egg parasitoids. Another assumption is that females are able to detect the presence of high population densities of parasitic wasps. This is reported for water striders (Hirayama \& Kasuya, 2009) and is likely to be true of other groups of aquatic insects. Moreover, habitat selection by adult odonates is significantly affected by previous experience of differences in habitat quality (Switzer, 1997). Thus, it is likely that damselflies, like water striders, retain a memory of the risk at the natal site, even when there is no danger of attack by parasitoids.

The other explanation may be related to other advantages affecting survival regardless of egg parasitism. The potential benefits associated with the stability of a water environment and greater overwinter survival of eggs may compensate for the high costs associated with underwater oviposition (Corbet, 1999; Heywood \& Walling, 2007). All the results, however, indicate that underwater oviposition in damselflies is a facultative oviposition strategy (Dolný et al., 2014) inasmuch as an individual utilizes it only if the benefits (preventing various types of predation, including egg parasitism) outweigh the potential risks of submerged oviposition.
ACKNOWLEDGEMENTS. This study was conducted in connection with an Institute of Environmental Technologies project, reg. no. CZ.1.05/2.1.00/03.0100, supported by the Research and Development for Innovations Operational Programme financed by the Structural Funds of the European Union, the state budget of the Czech Republic project LO1208 of the National Feasibility Programme I., Grant No. SGS32/PřF/2014 from the University of Ostrava and Grant No. 42110/1312/3118 from the Internal Grant Agency of Czech University of Life Sciences Prague. We would like to thank Z. Duriš (University of Ostrava) and P. Pavlík (Botanical Garden and Arboretum Stramberk) and four anonymous reviewers for their advice at the outset of this research.

\section{REFERENCES}

Amano H., Hayashi K. \& Kasuya E. 2008: Avoidance of egg parasitism through submerged oviposition by tandem pairs in the water strider, Aquarius paludum insularis (Heteroptera: Gerridae). - Ecol. Entomol. 33: 560-563.

Askew R.R. \& Shaw M.R. 1986: Parasitoid communities: their size, structure and development. In Waage J. \& Greathead D. (eds): Insect Parasitoids. Academy Press, London, pp. 225264.

BenNetT A.M.R. 2008: Global diversity of hymenopterans (Hymenoptera; Insecta) in freshwater. - Hydrobiologia 595: 529-534.

Bretz F., Hothorn T. \& Westfall P. 2010: Multiple Comparisons Using R. Chapman and Hall/CRC, Boca Raton, FL, 205 pp.

CoRbet P.S. 1999: Dragonflies: Behavior and Ecology of Odonata. Harley Books, Colchester, 829 pp.

Crawley M.J. 2007: The R Book. Wiley-Blackwell, Chichester, $1076 \mathrm{pp}$.

Dijkstra K.-D.B. \& Lewington R. 2006: Field Guide to the Dragonflies of Britain and Europe. British Wildlife Publishing, Dorset, $320 \mathrm{pp}$.

Dolný A., Helebrandová J., Rusková T., Šigut M. \& Harabiš F. 2014: Ecological aspects of underwater oviposition in Lestes sponsa (Odonata: Lestidae). - Odonatologica 43(3/4): in press.

FINCKE O.M. 1986: Underwater oviposition in a damselfly (Odonata, Coenagrionidae) favors male vigilance and multiple mating by females. - Behav. Ecol. Sociobiol. 18: 405-412.

Fursov V.N. 1995: A review of Chalcidoidea (Hymenoptera) parasitizing the eggs of aquatic insects in Europe. - Bull. Irish Biogeogr. Soc. 18: 2-12.

GibBons D.W. \& PAIN D. 1992: The influence of river flow rate on the breeding behavior of Calopteryx damselflies. - J. Anim. Ecol. 61: 283-289.

Henriquez N.P. \& Spence J.R. 1993: Host location by the gerrid egg parasitoid Tiphodytes gerriphagus (Marchal) (Hymenoptera, Scelionidae). - J. Insect Behav. 6: 455-466.

HeYwood M.J.T. \& Walling D.E. 2007: The sedimentation of salmonid spawning gravels in the Hampshire Avon catchment, UK: implications for the dissolved oxygen content of intragravel water and embryo survival. - Hydrol. Process. 21: 770-788.

Hirayama H. \& Kasuya E. 2008: Factors affecting submerged oviposition in a water strider: level of dissolved oxygen and male presence. - Anim. Behav. 76: 1919-1926.

Hirayama H. \& Kasuya E. 2009: Oviposition depth in response to egg parasitism in the water strider: high risk experience promotes deeper oviposition. - Anim. Behav. 78: 935-941.

Hirayama H. \& Kasuya E. 2010: Cost of oviposition site selection in a water strider Aquarius paludum insularis: egg mortal- 
ity increases with oviposition depth. - J. Insect Physiol. 56: 646-649.

JöDICKE R. 1997: Die Binsenjungfern und Winterlibellen Europas. Die Libellen Europas 3. Neue Brehm-Bücherei 631, WestarpWissenschaften, Magdeburg, 277 pp.

MARTENS M. 2001: Initial preference of oviposition sites: discrimination between living and dead plant material in Sympecma fusca and Coenagrion caerulescens (Odonata: Lestidae, Coenagrionidae). - Eur. J. Entomol. 98: 121-123.

Matushkina N. \& Gorb S. 2007: Mechanical properties of the endophytic ovipositor in damselffies (Zygoptera, Odonata) and their oviposition substrates. - Zoology 110: 167-175.

Miller P.L. 1994: The effect of oxygen lack on egg hatching in an Indian dragonfly, Potamarcha congener. - Physiol. Entomol. 17: $68-72$.

R Development Core Team 2011: R: A Language and Environment for Statistical Computing. R Foundation for Statistical Computing, Vienna [Available from http://www.R-project.org]

Santolamazza S., Baquero E. \& Cordero-Rivera A. 2011: Incidence of Anagrus obscurnus (Hymenoptera: Mymaridae) egg parasitism on Calopteryx haemorrhoidalis and Platycnemis pennipes (Odonata: Calopterygidae, Platycnemididae) in Italy. - Entomol. Sci. 14: 366-369.
SPENCE J.R. 1986: Interactions between the scelionid egg parasitoid Tiphodytes gerriphagus (Hymenoptera) and its gerrid hosts (Heteroptera). - Can. J. Zool. 64: 2728-2738.

SternberG K. \& Buchwald R. 1999: Die Libellen BadenWürttembergs. Band 1: Allgemeiner Teil. Kleinlibellen (Zygoptera). Eugen Ullmer, Stuttgart, $468 \mathrm{pp}$.

STRAND M.R. 1986: The physiological interactions of parasitoids with their hosts and their influence on reproductive strategies. In Waage J. \& Greathead D. (eds): Insect Parasitoids. Academy Press, London, pp. 97-136.

Tsubaki Y., Kato C. \& Shintani S. 2006: On the respiratory mechanism during underwater oviposition in a damselfly $\mathrm{Ca}$ lopteryx cornelia Selys. - J. Insect Physiol. 52: 499-505.

WAAGE J.K. 1984: Female and male interactions during courtship in Calopteryx maculata and C. dimidiata (Odonata: Calopterygidae): Influence of oviposition behaviour. - Anim. Behav. 32: 400-404.

Received February 7, 2014; revised and accepted October 6, 2014 Prepublished online November 11, 2014 